Research Article

\title{
Epidemiological study of socio demographic factors in relation to depression among the elderly people in a rural area of Chittoor district of Andhra Pradesh, India
}

\author{
Sharvanan Eshwaran Udayar *, Devi Vara Prasad
}

Department of Community Medicine, PES Institute of Medical Sciences and Research, Kuppam, Andhra Pradesh, India

Received: 12 October 2015

Accepted: 18 November 2015

\section{*Correspondence:}

Dr. Sharvanan Eshwaran Udayar,

E-mail: saravananudayar83@gmail.com

Copyright: ( $)$ the author(s), publisher and licensee Medip Academy. This is an open-access article distributed under the terms of the Creative Commons Attribution Non-Commercial License, which permits unrestricted non-commercial use, distribution, and reproduction in any medium, provided the original work is properly cited.

\section{ABSTRACT}

Background: Population ageing is a major global demographic trend in the twenty-first century and is progressing at a rapid phase in developing countries. Depression is a common mental disorder in the old age and it continues to be an under-recognized and undertreated disorder particularly in rural areas. The main objective of the study was to assess the prevalence of depression among elderly persons living rural area and to determine the factors influencing it so that appropriate preventive measures can be recommended.

Methods: Community based cross sectional study was undertaken in of Chittoor District in Andhra Pradesh state. Data was collected regarding socio-demographic profile and depression by using a semi structured and pretested questionnaire \& analyzed using SPSS software.

Results: Of the 451 subjects who participated in the study, the overall prevalence of depression among the studied population was $38.8 \%$.Females with depression (47.5\%) were more, compared to males (32\%). Depression among 60-69 years age group people was more (44.5\%) than remaining age groups. Depression was high among people who were alone like widowed, divorced, illiterate, poor socio economic status.

Conclusions: There is high prevalence of depression and is significantly associated with various socio demographic factors considered in the study.

Keywords: Population ageing, Depression, Elderly, Socio demographic factors

\section{INTRODUCTION}

Population ageing is the process which involves a rise in proportion of older persons in the total population and it is a major global demographic trend in the twenty-first century. ${ }^{1}$ This process of population ageing, which started first in the developed regions, is progressing at a rapid phase in developing countries, including those with large youth populations. ${ }^{2}$ It can be attributed to rise in life expectancy brought about by better nutrition, sanitation, health care, education and economic well-being etc. ${ }^{1}$
Currently in India 72 million people aged above 60 years are living and it is expected to reach 179 million in 2031 and further to 301 million in 2051. ${ }^{3}$ Older person's contributions in care giving, volunteering, and passing cultural traditions to younger generations are invaluable. Yet, they have weak social support networks, lack income, and are subjected to discrimination and abuse. Chronic and degenerative diseases which are more common in old ages increase the risk of depression, which in turn has a negative impact on the course of medical illness. ${ }^{4}$ 
Depression is a common mental disorder in the old age that presents with depressed mood, loss of interest or pleasure, decreased energy, feelings of guilt or low selfworth, disturbed sleep or appetite, and poor concentration. ${ }^{5}$ Reports show that the depression is the third leading cause of global disease burden, and will be the leading cause of disease burden by the year 2030 . Though effective treatments are available, it continues to be an under-recognized and undertreated disorder as it is difficult to diagnose at primary health settings, among the elderly living in the rural areas in particular. ${ }^{4}$ Hence with this background, the study was undertaken to assess the prevalence of depression among elderly persons living rural area and to determine the factors influencing it so that appropriate preventive measures can be recommended.

\section{METHODS}

Community based cross sectional study was undertaken for a period of six months (July-December 2014) in the villages of Ramakuppam Mandal of Chittoor District in Andhra Pradesh State. The sample size obtained by using the formula $4 \mathrm{pq} / \mathrm{d}^{2}$ with $10 \%$ allowable error was 327 based on the study done in rural Andhra Pradesh, in which the overall prevalence of depression due to economic insecurity among old age was around $52.5 \%{ }^{6}$ However, a desired sample of 533 elderly people was considered adequate for the study.

Multistage sampling design was used in the study. In the first stage the gram panchayaths in the Ramakuppam mandal were listed, out of 17 gram panchayaths three were selected randomly. Thus Manendram, Ramakuppam and Chaldiganipalli gram panchayaths were selected. The revenue villages in the each of the Gram panchayats were listed and two villages from each Gram panchayat were randomly selected. Athikuppam, Chinthakuppam from Manendram gram panchayaths and Mittapalli, Kempasamudram from Ramakuppam gram panchayat and Burugumakulapalli, Chaldiganapalli villages from Chaldiganipalli gram panchayats were included in the study. Approximately 75 individuals aged 60 years and above were selected from each village for the study by house to house visit. The first house on the left hand side was visited and subsequently the remaining households were followed by following the left hand method, until 75 individuals were interviewed. Only one individual from each household was included in the study. If any individual was not present at the time of first visit, a repeat visit was made to the house with prior information to the household members. Households were excluded when the elderly persons were not available even after three visits to the house.

Data was collected by using a semi structured and pretested questionnaire after obtaining informed consent from each participant explaining that the information will be kept confidential. All participants were assessed face to face and socio demographic data were obtained in the same interview. The modified BG Prasad scale was used to classify socioeconomic status. ${ }^{7}$ Geriatric Depression Scale (GDS-15) was used to assess depression. ${ }^{8}$ Scores of 0-4 were considered normal; 5-8 indicated mild depression; 9-11 moderate depression and 12-15 severe depression. Old age pension details like availing, reasons for not availing and economic dependency were included. Statistical analysis was performed using SPSS version 19. Approval for the study was obtained from the PESIMSR ethics committee.

\section{RESULTS}

Of the 451 subjects who participated in the study (Table 1), 253(56.1\%) were males and 198(43.9\%) were females. Majority of them fall under the age group of 6069 years i.e. 319 people $(70.7 \%), 113(25.1 \%)$ and $19(4.2 \%)$ people were of $70-79$ years and $80-89$ years respectively. $276(61.2 \%)$ people were married and remaining $175(38.8 \%)$ people were either widowed or unmarried or divorced. Illiterates constituted $54.1 \%$ i.e. 244 people and literates were $207(45.9 \%$ ) in number. Considering their socio economic status, people included in Class I were 41(9.1\%), Class II 93(20.6\%), Class III 109(24.2\%), Class IV 176(39\%), and 32(7.1\%) in Class V. Coming to their occupation, 379(84\%) people were working and earning and $72(16 \%)$ were at home (not earning). People from nuclear type of family were $140(31 \%)$ in number, from joint family and three generation family, they were $190(42.2 \%)$ and $121(26.8 \%)$ respectively. $197(43.7 \%)$ people were consulted for decisions, while 254(56.3\%) were not consulted.

The overall percentage of prevalence for depression among the studied population was $38.8 \%$, of which, major share was by the people suffering from the mild form of depression (Table 2).With respect to the various socio demographic variants influencing the prevalence of depression among the studied population (Table 3), females with depression $(47.5 \%)$ were more, compared to males $(32.0 \%)$. Depression among 60-69 years age group people was more $(44.5 \%)$ than remaining age groups. widowed/ unmarried/ divorced people with depression were more $(46.3 \%)$ than married people with depression. Percentage of illiterates with depression (46.3\%) was more compared to literates $(30.0 \%)$. Depression was more common with people from lower socio economic status than with the upper class people. With regard to the occupation, working and earning people $(38.0 \%)$ were less affected by depression compared to the people who were at home or not earning (43.1\%). Depression among people from Nuclear family $(49.3 \%)$ was more than in the people from other family types. Depression was more among the people who were not consulted for decisions $(42.9 \%)$ than the people who were consulted. 
Table 1: Various socio demographic factors considered for the study.

\begin{tabular}{|lll|}
\hline Variables & Number (n) & Percentage (\%) \\
\hline Age (years) & $142(44.5 \%)$ & $177(55.5 \%)$ \\
\hline $60-69$ & $29(25.7 \%)$ & $84(74.3 \%)$ \\
\hline $70-79$ & $4(21.1 \%)$ & $15(78.9 \%)$ \\
\hline $80-89$ & & $172(68.0 \%)$ \\
\hline Sex & $81(32.0 \%)$ & $104(52.5 \%)$ \\
\hline Male & $94(47.5 \%)$ & \\
\hline Female & & $94(53.7 \%)$ \\
\hline Marital status & $81(46.3 \%)$ & $182(65.9 \%)$ \\
\hline Widowed/ unmarried/ divorced & $94(34.1 \%)$ & $131(53.7 \%)$ \\
\hline Married & & $145(70.0 \%)$ \\
\hline Educational Status & $113(46.3 \%)$ & $30(73.2 \%)$ \\
\hline Illiterates & $62(30.0 \%)$ & $63(67.7 \%)$ \\
\hline Literates & & $68(62.4 \%)$ \\
\hline Socio-economic Status & $11(26.8 \%)$ & $102(58.0 \%)$ \\
\hline Class I & $30(32.3 \%)$ & $13(40.6 \%)$ \\
\hline Class II & $41(37.6 \%)$ & \\
\hline Class III & $74(42.0 \%)$ & $235(62.0 \%)$ \\
\hline Class IV & $19(59.4 \%)$ & $41(56.9 \%)$ \\
\hline Class V & & \\
\hline Occupation & $144(38.0 \%)$ & $131(50.7 \%)$ \\
\hline Working and Earning & $31(43.1 \%)$ & $126(66.3 \%)$ \\
\hline At home (not earning) & & $79(65.3 \%)$ \\
\hline Family Type & $69(49.3 \%)$ & \\
\hline Nuclear & $64(33.7 \%)$ & \\
\hline Joint & $42(34.7 \%)$ & \\
\hline Three Generation Family & $66(33.5 \%)$ & \\
\hline Consulted for decisions & $109(42.9 \%)$ & \\
\hline Yes & & \\
\hline No & & \\
\hline & & \\
\hline
\end{tabular}

Table 2: Prevalence of depression in the Studied Population.

Depression as per GDS Score

Absent

Mild

Moderate

Severe

\begin{tabular}{|ll|}
\hline Number $(\mathbf{n})$ & Percentage $\%$ \\
\hline 276 & $61.2 \%$ \\
\hline 95 & $21.1 \%$ \\
\hline 57 & $12.6 \%$ \\
\hline 23 & $5.1 \%$ \\
\hline
\end{tabular}

\section{DISCUSSION}

Prevalence of depression in the community samples of the elderly in India varied from $6 \%$ to $58 \%$ in various studies. ${ }^{9-12}$ In the current study, the overall prevalence of depression among the elderly was found to be $38.8 \%$ which is comparable to the findings by Vishal $\mathbf{J}$ et al $(47.9 \%)$ and Kumar $\mathrm{R}$ et al $(54.3 \%) .{ }^{10,11}$ Taking into account the various parameters included in the study, prevalence of depression is more among 60-69 years age group individuals, which can be explained by considering the 60 plus age as a transition period, where there is sudden loss of work, to which they are used to for many years.

Elderly females with depression were more compared to males, similar to the results in a study by Pracheth $\mathrm{R}$ et al in which percentage of females with depression was $31.39 \%$ while it was $25.93 \%$ among males. ${ }^{3}$ These results were in contrary with the study done by Sandhya GI in which depression among females was $22.9 \%$ and in males it was $29.1 \% .^{13}$ Though they render invaluable services in the family, females are always neglected part in the society, particularly in the rural areas. They are still neglected when they can't do these things due to 
advancing age and this leads to depression which may also be associated with chronic illnesses, loss of spouse as life expectancy among males is less compared to females. $^{14}$

Table 3: Association between depression and the socio demographic factors.

\begin{tabular}{|c|c|c|c|c|}
\hline Variables & Depression Present n(\%) & Depression Absent n(\%) & $\chi^{2}$ value & p-value \\
\hline \multicolumn{5}{|l|}{ Age (years) } \\
\hline $60-69$ & $142(44.5 \%)$ & $177(55.5 \%)$ & \multirow{3}{*}{15.1} & \multirow{3}{*}{0.001} \\
\hline $70-79$ & $29(25.7 \%)$ & $84(74.3 \%)$ & & \\
\hline $80-89$ & $4(21.1 \%)$ & $15(78.9 \%)$ & & \\
\hline \multicolumn{5}{|l|}{ Sex } \\
\hline Male & $81(32.0 \%)$ & $172(68.0 \%)$ & \multirow[b]{2}{*}{11.2} & \multirow[b]{2}{*}{0.001} \\
\hline Female & $94(47.5 \%)$ & $104(52.5 \%)$ & & \\
\hline \multicolumn{5}{|l|}{ Marital status } \\
\hline Widowed/ unmarried/divorced & $81(46.3 \%)$ & $94(53.7 \%)$ & \multirow[b]{2}{*}{8.3} & \multirow[b]{2}{*}{0.004} \\
\hline Married & $94(34.1 \%)$ & $182(65.9 \%)$ & & \\
\hline \multicolumn{5}{|l|}{ Educational Status } \\
\hline Illiterates & $113(46.3 \%)$ & $131(53.7 \%)$ & \multirow[b]{2}{*}{12.6} & \multirow[b]{2}{*}{0.000} \\
\hline Literates & $62(30.0 \%)$ & $145(70.0 \%)$ & & \\
\hline \multicolumn{5}{|l|}{ Socio-economic Status } \\
\hline Class I & $11(26.8 \%)$ & $30(73.2 \%)$ & \multirow{5}{*}{10.4} & \multirow{5}{*}{0.03} \\
\hline Class II & $30(32.3 \%)$ & $63(67.7 \%)$ & & \\
\hline Class III & $41(37.6 \%)$ & $68(62.4 \%)$ & & \\
\hline Class IV & $74(42.0 \%)$ & $102(58.0 \%)$ & & \\
\hline Class V & $19(59.4 \%)$ & $13(40.6 \%)$ & & \\
\hline \multicolumn{5}{|l|}{ Occupation } \\
\hline Working and Earning & $144(38.0 \%)$ & $235(62.0 \%)$ & \multirow[b]{2}{*}{0.65} & \multirow[b]{2}{*}{0.41} \\
\hline At home (not earning) & $31(43.1 \%)$ & $41(56.9 \%)$ & & \\
\hline \multicolumn{5}{|l|}{ Family Type } \\
\hline Nuclear & $69(49.3 \%)$ & $71(50.7 \%)$ & \multirow{3}{*}{9.4} & \multirow{3}{*}{0.009} \\
\hline Joint & $64(33.7 \%)$ & $126(66.3 \%)$ & & \\
\hline Three Generation Family & $42(34.7 \%)$ & $79(65.3 \%)$ & & \\
\hline \multicolumn{5}{|l|}{ Consulted for decisions } \\
\hline Yes & $66(33.5 \%)$ & $131(66.5 \%)$ & \multirow[b]{2}{*}{4.1} & \multirow[b]{2}{*}{0.04} \\
\hline No & $109(42.9 \%)$ & $145(57.1 \%)$ & & \\
\hline
\end{tabular}

Illiteracy and lower socio economic status also influenced the prevalence of depression as subjects with these backgrounds are most affected by depression compared to their counterparts. It can be explained in terms of knowledge and awareness to health and disease, and access to health services.

Depression was more among the people who were widowed or divorced, and living with nuclear families, which can be attributed to the loneliness that has a very bad effect on the mental health, leading to increased feeling of worthlessness, depression etc.

\section{CONCLUSION}

Present study shows higher depression rates among females, illiterates, those who are living alone, and people from low socio economic status. There is a statistically significant association of these factors with depression among the studied elderly population. As Population ageing is the current trend, Community based health education towards depression among the elderly is to be done because depression is presented as medically unexplained somatic symptoms or masked depression in majority of the cases. Also that, depression is cyclically related to chronic illness, and is heritable to some extent as suggested by some studies; screening campaigns for depression should be included in the national programs. ${ }^{15}$

Funding: No funding sources

Conflict of interest: None declared

Ethical approval: The study was approved by the Institutional Ethics Committee

\section{REFERENCES}

1. Population Division, DESA, United Nations World Population Ageing : 1950-2050. 
2. United Nations Population Fund. Report on the status of elderly in the selected states of India 2011.New Delhi, India, 2012.

3. Pracheth R, Mayur SS, Chowti JV. Geriatric depression scale: A tool to assess depression in elderly. Int J Med Sci Public Health. 2013;2:31-5.

4. Pattanayak RD, Sagar R. Depressive Disorders in Indian Context: A Review and Clinical Update for Physicians. Journal of the Association of Physicians of India. 2014;62(9):827-32.

5. Depression : A Global Public Health Concern. WHO.2012.

6. Udayar SE, Devika PJ, Konduru RK, Patil SD. A study of economic dependency and its relation to depression among elderly people in rural area of Chittoor district, Andhra Pradesh. Int J Health Sci Res. 2014;4(12):100-5.

7. Dudala SR, Reddy KAK, Prabhu GR. Prasad's socio-economic status classification- An update for 2014. Int J Res Health Sci. 2014;312(3):875-8.

8. Jerome A Yesavage. Geriatric Depression Scale; Psychopharmacology Bulletin. 1988;24(4):709-11.

9. Swarnalatha N. The Prevalence of Depression among the Rural Elderly in Chittoor District, Andhra Pradesh. Journal of Clinical and Diagnostic Research. 2013;7(7):1356-60.
10. Vishal J, Bansal RK, Swati P, Bimal T. A study of depression among aged in Surat city. National Journal of Community Medicine. 2010;1(1):47-9.

11. Rajkumar AP, Thangadurai P, Senthilkumar P, Gayathri K, Prince M, Jacob KS. Nature, prevalence and factors associated with depression among the elderly in a rural south Indian community. International Psychogeriatrics. 2009;21:372-8.

12. Venkoba RA. Psychiatry of old age in India. International Review of Psychiatry. 1993;5:165-70.

13. Sandhya GI. Geriatric Depression and Related Factors-A Cross sectional Study from a Rural Community in South Kerala. Journal of the Indian Academy of Geriatrics .2010;6(2):61-3.

14. Global Health Observatory Data Repository: Life expectancy - Data by country. Geneva, Switzerland: World Health Statistics 2015, World Health Organization, WHO. 2015.

15. Levinson DF. The genetics of depression: a review. Biol Psychiatry. 2006;60:84-92.

Cite this article as: Udayar SE, Prasad DV.

Epidemiological study of socio demographic factors in relation to depression among the elderly people in a rural area of Chittoor district of Andhra Pradesh, India. Int J Community Med Public Health 2016;3:161-5. 